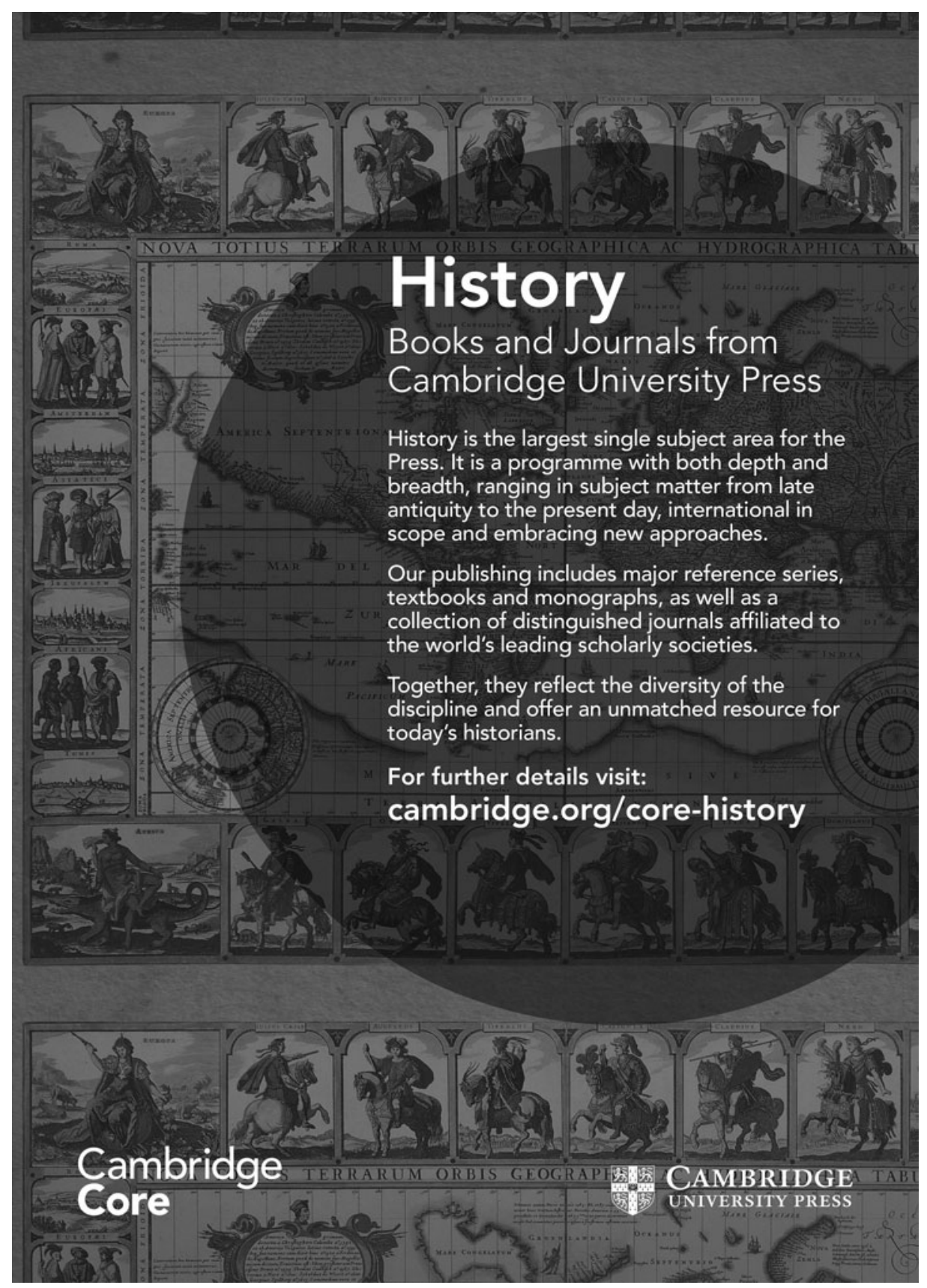




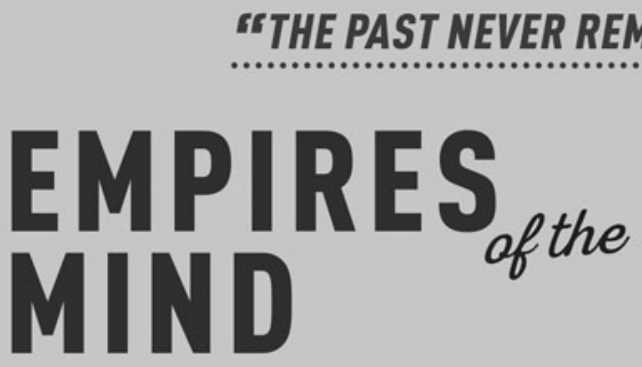

THE COLONIAL PAST AND THE POLITICS OF THE PRESENT

\section{ROBERT GILDEA}

"ss The past never remains in the past, Robert Gildea skilfully reminds us as he recounts the brutal histories of both British and French colonial and neo-colonial ventures. This is a book that insists on the connections between what happens/ed 'out there' and what happens/ed 'in here' and helps us to think through that complex and dangerous entanglement, which continues to inform our contemporary politics today."

CATHERINE HALL, author of Civilising Subjects: Metropole and Colony in the English Imagination 1830-1867

"The empires of the future would be the empires of the mind" declared Churchill in 1943, envisaging universal empires living in peaceful harmony. Robert Gildea exposes instead the brutal realities of decolonisation and neo-colonialism which have

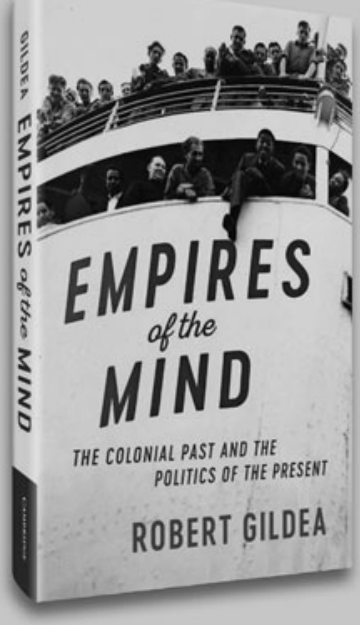

Part of The Wiles Lectures

Hardback | 978-1-107-15958-7 $366 \mathrm{pp}$. $\mid 20 \mathrm{~b} / \mathrm{w}$ illus.

\section{$\$ 24.95 / \mathbf{\$ 2 0 . 0 0}$}

shaped the postwar world. Even after the rush of French and British decolonisation in the 1960 s, the strings of economic and military power too often remained in the hands of the former colonial powers. The more empire appears to have declined and fallen, the more a fantasy of empire has been conjured up as a model for projecting power onto the world stage and legitimised colonialist intervention in Afghanistan, Iraq, and Syria. This aggression, along with the imposition of colonial hierarchies in metropolitan society, has excluded, alienated and even radicalised immigrant populations. Meanwhile, nostalgia for empire has bedevilled relations with Europe and played a large part in explaining Brexit.

\section{www.cambridge.org} @cambUP_History

疄圈 CAMBRIDGE UNIVERSITY PRESS 


\section{SUBMISSION OF ARTICLES}

If you want to submit an article for our editors to look at, please send it to: Itinerario@hum.leidenuniv.nl

\section{Authors submitting work to Itinerario} are advised to follow the submission guidelines as closely as possible to minimise editorial changes to their work and thus minimise the chance of introducing errors inadvertently into your writing. The guidelines are based on and are similar to the recommendations found in the internationally known and respected Chicago Manual of Style, 15th edition, and readers are encouraged to refer to that work should they require clarification. Likewise, they can always address any particular questions to the editors at Itinerario@hum.leidenuniv.nl.

Submission guidelines can be found at https://www.cambridge.org/core/journals/ itinerario/information/instructionscontributors

\section{COPYING}

This journal is registered with the Copyright Clearance Center, 222 Rosewood Drive, Danvers, MA 01923, USA. Organisations in the USA who are also registered with the C.C.C. may, therefore copy material (beyond the limits permitted by, sections 107 and 108 of U.S. Copyright law) subject to payment to the C.C.C of the per copy fee of $\$ 15.00$. This consent does not extend to multiple copying for promotional or commercial purposes. Code 01651153/15. ISI Tear Sheet Service, 3501 Market Street, Philadelphia, PA 19104, USA, is authorised to supply single copies of separate articles for private use only. Organisations authorised by the Copyright Licensing Agency may also copy material subject to the usual conditions. For all other use, permission should be sought from Cambridge or from the American Branch of Cambridge University Press.

Cover design: Anton Feddema, Amsterdam. Illustration: Courtesy of Cornell University - PJ Mode Collection of Persuasive Cartography, no. 1108.01.

Effective Vol. 33 (2009), Itinerario - Journal of Imperial and Global Interactions, is being covered by the Clarivate Journal Citation Report. 


\section{Itinerario}

the history of imperial and global interactions. Published for the Leiden University Institute for History and mindful of the University's entangled history with empire and colonialism, we encourage authors to take a global perspective. We aim to publish contributions which critically evaluate histories of empires, institutions, ideas, and networks across the globe, and the ways in which their legacies continue to shape the contemporary world.

Itinerario is affiliated with the Leiden Institute of Area Studies (LIAS) and the forum on European Expansion and Global Interaction (FEEGI) in the US.

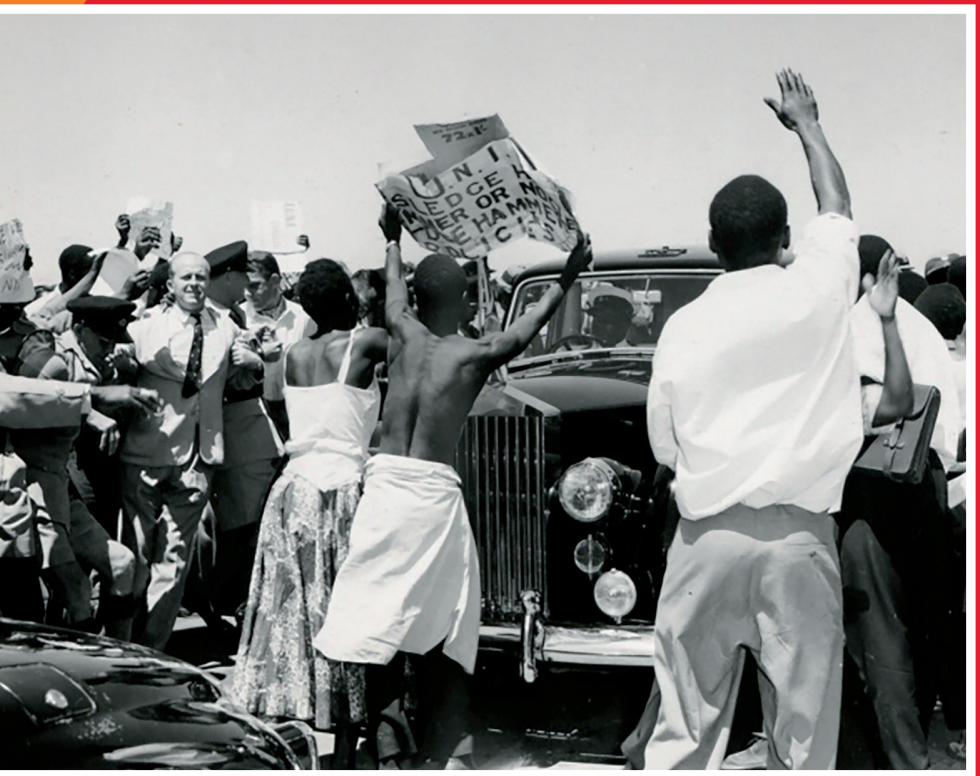

The United National Independence Party protests the visit of lan Macleod, Secretary of State for the Colonies, to Northern Rhodesia in March 1960. The "Year of Africa", now itself sixty years in the past, saw the independence of seventeen African nations as well as widespread anticolonial protests in others. Image courtesy National Archives, UK, CO 1069-125-10.

Cambridge Journals Online For further information about this journal please go to the journal web site at: journals. cam moridgelorged orgiti

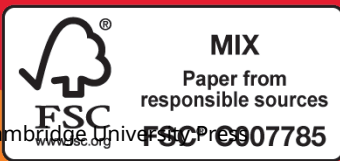

